\title{
WestVirginiaUniversity
}

THE RESEARCH REPOSITORY @ WVU

Graduate Theses, Dissertations, and Problem Reports

2005

\section{Psychology in character}

Neil M. Austin

West Virginia University

Follow this and additional works at: https://researchrepository.wvu.edu/etd

\section{Recommended Citation}

Austin, Neil M., "Psychology in character" (2005). Graduate Theses, Dissertations, and Problem Reports. 1575.

https://researchrepository.wvu.edu/etd/1575

This Thesis is protected by copyright and/or related rights. It has been brought to you by the The Research Repository @ WVU with permission from the rights-holder(s). You are free to use this Thesis in any way that is permitted by the copyright and related rights legislation that applies to your use. For other uses you must obtain permission from the rights-holder(s) directly, unless additional rights are indicated by a Creative Commons license in the record and/ or on the work itself. This Thesis has been accepted for inclusion in WVU Graduate Theses, Dissertations, and Problem Reports collection by an authorized administrator of The Research Repository @ WVU. For more information, please contact researchrepository@mail.wvu.edu. 


\title{
PSYCHOLOGY IN CHARACTER
}

\author{
by
}

Neil M. Austin

Thesis submitted to the College of Creative Arts At West Virginia University In partial fulfillment of the requirements for the degree of Master of Fine Arts

\author{
in \\ Acting
}

Approved by

Jerry McGonigle, Committee Chairperson

Phil Beck

Dr. Jay Malarcher

Dr. Don Fidler

Department of Theatre and Dance

Morgantown, West Virginia 2005

Keywords: Psychology, Acting, Character

Copyright 2005 


\title{
Abstract
}

\section{PSYCHOLOGY IN CHARACTER}

\author{
by Neil M. Austin
}

Does Psychology help create character? How does Psychology build an interesting person on the stage or screen? Psychology helps us understand why we act the way we do? Psychology is a great tool for actors to bridge the history of the character to his or her present actions. Through my performance of Vassily from Kolonists, Nick from The Time of Your Life and my work with Psychiatrist Dr. Don Fidler, I will explain what my actor process is and how psychology has helped me in creating these characters. 


\section{Dedication}

The author wishes to thank his parents for their endless support and guidance. 


\section{Acknowledgments}

The author wishes to acknowledge Phil Beck, Dr. Don Fidler, Jerry McGonigle, and Dr. Jay Malarcher for all their knowledge and guidance 


\section{Table of Contents}

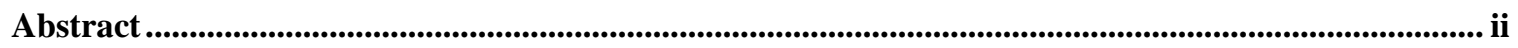

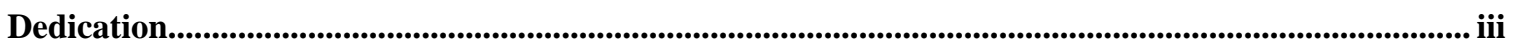

Acknowledgments........................................................................................................................................ iv

Table of Contents.................................................................................................................................................. v

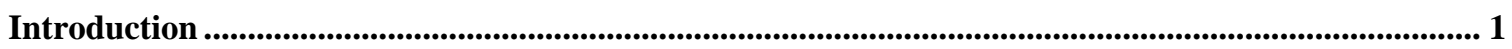

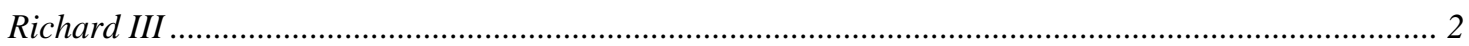

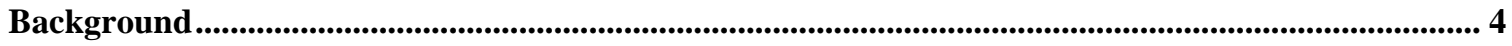

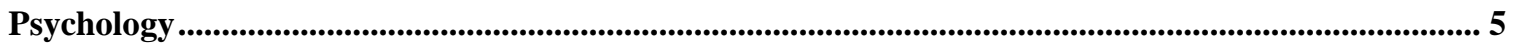

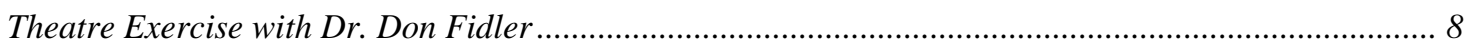

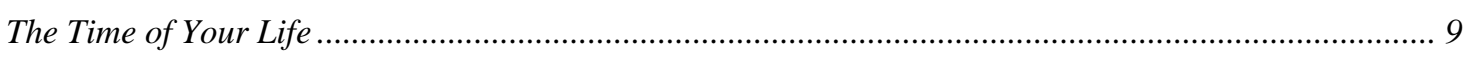

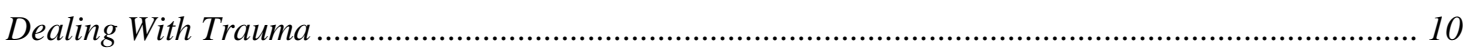

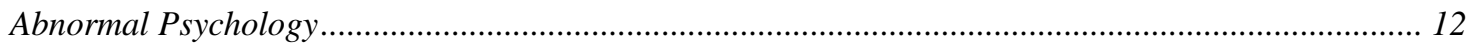

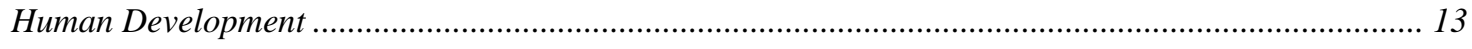

Given Circumstances......................................................................................................................................... 16

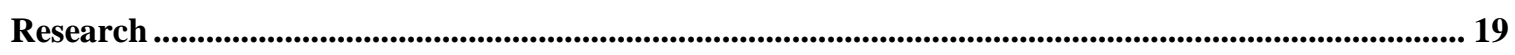

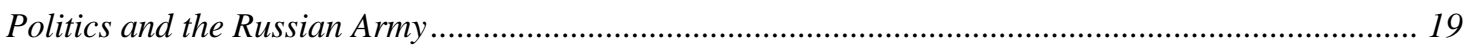

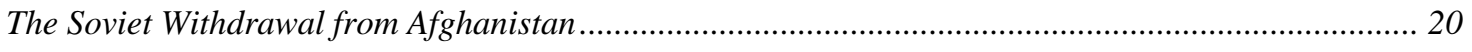

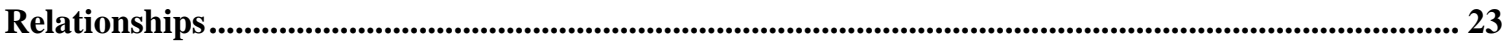

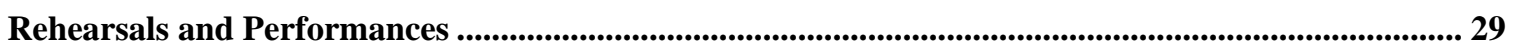

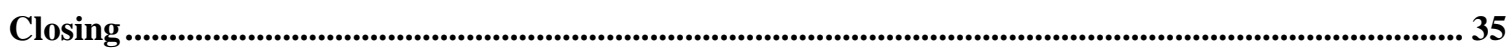

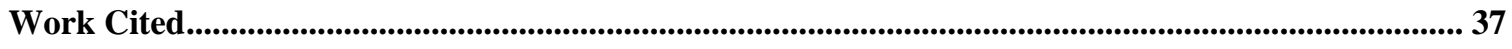

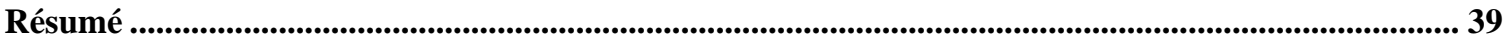




\section{Introduction}

Does the study of psychology benefit the actor in creating character? This Thesis will demonstrate that the use of Psychology is an important aid in creating character. It will be based on my actor-process in creating the character of Vassily in Kolonists. Within the psychology portion there are sections about post-traumatic stress disorder, alcoholism and what I have learned from in The Psychiatry for Actor Module taught by Dr. Don Fidler, M.D. My performance of Nick in The Time of Your Life will be referenced to support my ideas. There will also be a detailed explanation of my research, character given circumstances and a thorough account of the rehearsal process and the individual performances of Kolonists.

In the early stages of character development, a psychological examination will clarify why a character behaves the way he does. My process consists of, first reading the play to find the story being seen through the eyes of the audience. Read the play again and break the play up into actor units while looking for my character's objectives. Then look for all the given circumstances in the play, time, location and historical context in regards to my character. Write down everything each character says about the character. This would be my normal process of character development for a show. At this point the process psychology is added. Psychology gives the actor a better understanding of how the mind of the character works. By understanding the human mind, the actor's performance becomes more specific, because psychology helps the actor answer the question: "What in the past makes me act this way?” Actors do not need a degree in psychology to utilize its teachings. A psychological handbook for actors, would give enough knowledge to aid them in their own character development. This handbook would contain all the psychological disorders with descriptions of symptoms, causes, time of onset and how the disease affects the patient and those around them. The Psychological handbook for actors would also contain psychological theories of human development, by Erickson and Sigmund Freud.

The great roles in drama go through traumatic events during or before the play. These events cause psychological problems that explain why the characters act the way they do. Psychological problems not only affect the mind, but they also affect the 
person's general health: causing tension, sickness, sleepiness, heart attacks, panic attacks, and anxiety. With enough exploration of the character's mental state and the traits that go along with that state of mind early in the acting process the actor won't need to think about it during performance, because it will already be built into the character.

\section{Richard III}

I researched Shakespeare's villain, Richard III, and studied his character traits and actions and looked for comparisons in a personality disorder that would match the character's actions. I looked through the DSM-IV, The Diagnostic and Statistical Manual of Mental Disorders and Richard fit into the anti-social personality disorder. These traits include:

- $\quad$ Failure to conform to social norms with respect to lawful behavior.

- $\quad$ Deceitfulness, as indicated by repeated lying, or conning others for personal profit or pleasure.

- $\quad$ Irritability and aggressiveness, as indicated by repeated physical fights or assaults.

- $\quad$ Reckless disregard for safety of self and others.

- $\quad$ Lack of remorse, as indicated by being indifferent to or rationalizing having hurt, mistreated, or stolen from another.(DSM-IV, 649,650)

After studying Richard's given circumstances and characteristics and the research I found in the DSM-IV, I came to the conclusion that Richard had anti-social personality disorder. There is a familial pattern with this mental disorder; meaning that there is a higher risk to children with parents who have the same disorder. I used this information to create a childhood for Richard where his father was plagued by the same disease. Understanding the different behaviors and the source of the disease added to the characters traits the playwright provided helped me in a short amount of time to create a very specific background. There was more evidence within the dialog between Richard and his mother to back up my ideas. Richard regresses to childhood whenever his mother is around. In scene IV, iv Richard is confronted by his mother and regresses to his childhood. 
Duchess. No, by the holy rood, thou know'st it well, Thou cam'st on earth to make the earth my hell.

A grievous burthen was thy birth to me, Techy and wayward was thy infancy; Thy school-days frightful, desp'rate, wild, and furious

Thy prime of manhood daring, bold, and venturous;

Thy age confirm'd, proud, subtle, sly, and bloody,

More mild, but yet more harmful—-kind in hatred.

What comfortable hour canst thou name That ever grac'd me with thy company?

K. Richard. Faith, none, but Humphrey Hour, that

Call'd your Grace

To breakfast once, forth of my company.

If I be so disgracious in your eye, Let me march on and not offend you, madam.

Strike up the drum.

Duchess. I prithee hear me speak.

K. Richard. You speak to bitterly.

Dutchess. Hear me a word;

for I shall never speak to the again

K. Richard. So. (Lines 166-184)

Richard's mother talks about his personality in childhood, she calls him, “A grievous burden to me...Thy school-days frightful, desp’rate, wild, and furious.” (Riverside Shakespeare, 729) Knowing that the Anti-Social Personality Disorder begins in adolescence and Richard's mother's words about his school days and Richards actions around his mother support my hypothesis. 


\section{Background}

I received my undergraduate degree at Salem State College in Massachusetts with a B.A. in Theatre and a Minor in Psychology. The psychology classes I took were Abnormal Psychology, Theories of Learning, Child and Adolescent Psychology, and Adult and Old Age Psychology. They have all helped me to understanding how the mind works, how people interact with each other and how people deal with trauma. Since graduation I have been trying to combine the study of psychology to my acting. This background has helped me to analyze a character more thoroughly. This extra step has helped me to fill in gaps in my performance where I am lost and don't know how or why my character act that way.

After college, I spent two years working as an adolescent counselor for troubled teen boys in an intensive program and school called The Wreath School. Boys from the age of twelve to eighteen years old were sent by their school or by the court because of deviant behavior. This school was the last option before a mental hospital or jail. We used a behavioral modification system at the school, based on positive re-enforcement. Some of the Psychological problems we dealt with were psychotic, pre-schizophrenic, attention deficit hyperactivity disorder and obsessive compulsive disorder and many had drug and alcohol problems. Once I had to hold a distraught teenager down to prevent him from smashing his head into the ground. At the time I could not understand how a child could do something so violent to himself. After the event I read his chart and was able to get a better understanding of why this child was acting out. The boy had only one parent and had been sexually and physically abused as a child. Another boy found his parent dead with a heroin needle sticking in her arm. These traumas occurred in early childhood and affected their behaviors and mental development. One of my superiors said when the stress of the job gets too much he reads the patient's files to understand where they came from. 


\section{Psychology}

This section will focus on the use of psychology in creating the character Vassily in Kolonists; my work with Dr. Don Fidler in his Psychiatry for Actors class and my work with him on the role of Nick in The Time of Your Life. I will add my psychological research that aided my work in both plays and talk about how that affected me in my acting process.

After my character research for Vassily, I realized he was a severe alcoholic and was suffering from post-traumatic stress disorder. Vassily was never on stage when he did not have a drink or was asking for one and he had very violent and abusive tendencies. I had a need to know how an alcoholic thinks and feels, how they physically feel when they need a drink, when there drunk and how they use it as a crutch to avoid feeling emotions. The definition of alcoholism, “This category is for patients whose alcohol intake is great enough to damage their physical health or their social functioning, or when it has become a prerequisite to normal functioning.” (Krasner,Ullmann, 445) There were many times I would be in conversation with another character and be thinking about getting a drink. As the play built to its climax that need for a drink really took over my internal monologue, causing my character irritated. Alcohol is a depressant, which can have an interesting affect on patients, who at first may use the alcohol to get over nerves or stress.

The first thing to be depressed is the power of restraint...The solitary become gregarious, shy men loquacious and the fearful foolhardy. Self-critical men can treat others kindly, sexually inhibited men dare to be amorous. (Krasner and Ullmann, 448)

The more the alcoholic drinks the more they become depressed and the more depressed they get the more they try to escape to the bottle. They become anti-social, lose bodily function, have liver problems or failure, become aggressive and assault, and may give up eating.

Vassily has a real hard time going back to the house where he witnessed his father's adultery with his aunt. It is also difficult for Vassily to tell his family that he is turning his family's dacha into a whore house. On top of that Vassily will have to see his 
cousins that he hasn't seen in twenty years. These pressures cause Vassily to drink a great deal before he arrives at the dacha. One of Vassily’s first lines is “We'll have a nightcap first.”(Kolonists, 19). In his next line he says, "Make yourself useful and fix us a stiff one.” Vassily's demands for alcohol continue until he gets the vodka bottle. At first I was making the choice that I needed the drink, because I was anxious. That was the wrong objective to play. I realized with the wise direction of Phil Beck, my director that I needed to find a positive objective to play or the whole play would be one level. We came to the conclusion that I was looking to have a good time and party. Now the need for the drink was still there, but it was disguised by my need to have a good time. The drinking helped me to become the brave soldier I wanted to be in front of my family. Physically I had to deal with the task of acting like a rude, belligerent drunk. I used a sense memory exorcize taught to my fellow acting grad students and myself by Jerry McGonigle. In the exercise you imagine a drinking glass that you are very familiar with that has some meaning to you. The glass could be a shot glass, sifter or a beer glass. Then you need to imagine the strongest drink you've ever had in you life. I chose a Martini. We imagined every drink, the smell, the temperature, the taste, how it went down, how it made your stomach feel, your throat and how it affected the whole body. This continued until he made us stand up very fast, hoping to give us a head rush and it worked. We then walked around, seeing how it affected our walking. He then put us on one side of the room and made us tell jokes one at a time in front of the class. But he had us pretend it was eight in the morning and in acting class and we could not let the teacher know. I was so drunk I actually felt nauseous and needed to puke. The classroom part for me was the most important lesson for me, because it taught me that someone drunk does not want others to know how drunk they are. No one wants to seem stupid. Nobody wants to puke. They want to stop themselves from puking. Nobody wants to slur their speech so they compensate by overemphasize their words. When someone is drunk and tries to compensate like that they get louder and sound funny. In the play,I knew how every drink felt, how drunk I was getting and how that affected my speech and body. Also, I was aware of my emotional state after each drink. The idea was to build my physical, emotional and mental drunkenness until the climax of the scene where I was dry heaving and passing out. After my major drunk scene, I woke up and leave to go to the bathroom 
under the stars. I return after being attacked by Yakov and dragged on stage and thrown on the couch where I passed out again. I chose to slowly come back to consciousness, barely being able to keep my head up. Sense memory work really helped me believe this moment. I was doing that work from the beginning of the rehearsal process so it really became natural and I did not have to think about it or fake it, which gave me a sense of ease in the scene.

Another psychological disease that I explored in my character Vassily was post traumatic stress disorder.

- $\quad$ The person experienced, witnessed, or was confronted with an event or events that involved actual or threatened death or serious injury, or a threat to the physical integrity of self or others.

- recurrent and intrusive distressing recollections of the event, including images, thoughts, or perceptions.

- recurrent distressing dreams of the event

- feeling of detachment or estrangement from others

- unable to have loving feelings

- difficulty falling or staying asleep

- $\quad$ irritability or outbursts of anger

- $\quad$ exaggerated startle response (DSM-IV, 427-428)

There is plenty of evidence within the script to suggest Vassily was suffering from PTSD. Vassily was a soldier in the Russian Army. He was involved in wars in Angola and Afghanistan. The Russians involvement in the war in Afghanistan mirrored our involvement in Vietnam. That war was long and ugly. They lacked backing from other countries. Also they lacked backing from the Russian people. While in Afghanistan many soldiers became depressed and fell into drugs and alcohol. When he returned the Soviet Union fell apart and many of the military leaders were fired due to political differences. After his father and he were fired from the soviet army they started an illegal arms smuggling business. Vassily’s work in the Russian mafia caused him to be ashamed. The combination of the three traumatic events brought me to the conclusion that Vassily had PTSD.

PTSD has very specific traits that go along with the disease caused by a traumatic event or several events, like rape, molestation and war. Flashbacks of the event, denial 
and refusal to speak about the trauma are common. It is important to understand how you deal with these events so make it even more specific to the character. In the second act Vassily talks about how ugly the war was in Afghanistan. But he doesn't go into detail, he only says, “It was pretty fucking Ugly, son.”(Kononists, 57) After that quote he doesn’t speak for a page. I decided I was having a flashback during that moment caused by the conversation about the war.

\section{Theatre Exercise with Dr. Don Fidler}

Don Fidler is a Psychiatrist at West Virginia University with a passion for theatre, some of his idea of how human development can be used in the development of character have helped me in multiple roles. The first day I met Don Fidler he sat our graduate acting class in a row, in front of a chalk board, and asked for a volunteer. I raised my hand because I knew that his specialty was psychology. Before he took me aside he gave us some given circumstances for the group. We were third grade students sitting in a classroom. He took me aside and told me that I was a boy without a father; my mother severely beat me when things were not done correctly, and also the night before class she threw me in a boiling hot bathtub as punishment. It was also mentioned that since my father abandoned us, I was the man of the house and took on many of the responsibilities. After these given circumstances were given to me I was placed back into the class room with the other students. Once I sat down there was no attempt on my part to act. I was not trying to make choices or to portray a child neglected or beaten. I just was there. I was asked by the teacher to go up to the board and do a simple math problem. I was very tentative to get up, very slowly and controlled. I felt ashamed. All I wanted to do was not make a mistake. While I was doing these math problems I saw flashes of the night before being thrown into the scalding hot bath tub. This caused me to be even more careful not to make a mistake. Once I was finished, there was relief, but not full relief. There was still a great fear in me. I sat back down and one of the students tried to touch me on the shoulder. I immediately snapped my shoulder away and was prepared to hit her. I never thought about these actions, they were in my body. My shoulder pulling away was a true physical reaction to someone touching me. There was no intellectual 
thought about choices or where I should go or what I should do. It was a wonderfully freeing moment on stage to be out of my head and fully submersed in the situation. The events need to be specific to the actor to be successful. The bathtub was horrifyingly specific and that helped me to drop into the scene.

\section{The Time of Your Life}

I played the character Nick, the bartender/owner of a San Francisco honky tonk in The Time of Your Life. After my first reading I realized that my wife was dead. This psychological clue helped me create the rest of my character, by creating my main character objective around my wife's death. My overall objective was to take care of my bar and the people in it. The bar was my solace from thoughts of my great loss. The loss of my wife caused me many obstacles throughout the play. When my daughter comes into the bar, I scold her and send her home to her grandmother to make me supper. After that I return to the bar and take one shot, then say, "My Beautiful, beautiful baby, Anna she's you again.” I snapped at my baby because she reminded me of my wife and I don't want her to get hurt and leave me, as well. Also, when my daughter comes in, I have to fight with the image of my wife dying of cancer in her hospital bed. The outside world and my life outside the bar keep creeping in, pulling me away from my objective. The moment where I close eyes and talk to my wife, I disassociated myself from the bar. When I open my eyes I am unaware of what I did or said. There was a great deal of confusion and embarrassment. This was a very sticky point for me in the character process. I was thinking too much and forcing myself to think these thoughts. Once I took Don's advice about being unaware of my surroundings and the confusion it caused, there was clarity of action and not thought. That moment also caused several flashbacks of my wife. The two most prominent flashbacks were my wife dying on her death bed, gasping for air and the other was on are wedding day, her coming down the aisle and us having our first dance as a married couple. 


\section{Dealing With Trauma}

Many people have had to deal with horrific events that occurred in there lifetime, wars, violence, rape, hurricanes, floods, droughts, assassinations and terrorist attacks. Some of these events may not take place at the time of the play, but happened before the play and should be explored as part of the characters given circumstances. There are specific symptoms of stress and mental disorder caused by these events and even though the characters may not be mentally ill, there is a psychological residue left on the person. The tragedy of September Eleventh changed Americans forever. Depending on your age you will have different reactions to tragedies like September Eleventh. Immediately after the event, there is usually blank stares, numbness of the emotions and a feeling of disorientation, usually due to the victims search for understanding and reason. In John Weaver's book, Disasters: Mental Health Interventions, he speaks about the immediate reaction of the victims.

...when survivors were probably beginning to search their brains' memory bank for any similar events that they might be able to draw upon for guidance that they might be able to draw upon for guidance and strength. Unfortunately, most people probably found nothing comparable which could help them. Faced with a major trauma, most people simply cannot carry on with business as usual. (Weaver, 29)

After traumatic events there is nothing in their life to base it off of to find comfort. These victims are drastically searching for strength, but find nothing.

There are several methods to help an actor understand what is going on in the victims mind and body. The first stage is Alarm, also known as Fight or Flight. These are automatic biological reactions to trauma. There is a heightened state of arousal, a raise in blood pressure and the body creates an aggressive or a defensive mechanism to help with dealing with the event. Part two is called, Resistance to try to cope. Some symptoms are a lack of rest, can not deal with pressure, can become sick, mentally or physically. At this stage the victim can either deal with these problems or ignore them. Part Three is the Heroic Phase, which takes place immediately after the disaster. People work together to save lives or property. There is a heightened excitement and intensity. Part four is the 
Honeymoon Phase. Friends and family give support and often complete strangers give their support. Relief supplies come from all over the country. Optimism runs high, but it is short lived. The next stage comes too quickly after the Honeymoon Stage. The Disillusionment Phase occurs when promises of aid fall short and relief is taking too long to arrive. Victims begin to take control of their lives and attempt to deal with the loss on there own. Finally, there is the Reconstruction Phase. This period takes many years. It is the reconstruction period where the community moves back to the direction of normalcy. The understanding of these phases could really help with an actor that needed to portray a character immediately after a trauma or several years later. The actor could actually pinpoint the phase there character is in during the play.

During The Time of Your Life, my character runs out to the street to see his bitter rival, Blick, dead, with two bullet holes in him. He then had to deal with the trauma of viewing his enemy, who he had wished dead, murdered in the street. I stared blankly as I recounted to Joe the event that just took place. I was searching for answers to this shocking event and there was numbness to my emotions because I did not know what to think or how to feel.

In Weaver's book Disaster: Mental Health Interventions, he also speaks about the needs and reactions usually accompanied with a trauma.

1. Basic survival concerns.

2. Grief over loss of loved ones and/or prized possessions

3. Separation anxiety and fears for safety of significant others.

4. Regressive Behavior (e.g., thumb sucking in children).

5. Relocation and isolation anxieties.

6. Need to express thoughts and feelings about having experienced the disaster.

7. Need to feel one is part of the community and its rebuilding efforts.

8. Altruism and the desire to help others cope and rebuild their lives. (Weaver, 32)

There are possibilities to go even further with the specifics in the needs and reactions section. These psychological needs are perfect objectives to play for an actor. They are specific and are caused by the action of the play. After Blick's death many of 
the characters need to talk about the event, they need to be part of the community which prevents them from leaving the bar.

\section{Abnormal Psychology}

Abnormality is defined as behavior that violates the expectations of the society to the extent where there needs to be an intervention by mental health providers. These abnormalities can be great as character choices to explore during the actor process. During the rehearsal process of The Time of Your Life, I was exploring the idea of Nick being an obsessive compulsive. As I played with this idea I decided it did not fit the character and his given circumstances to be an obsessive compulsive.

Obsessive-compulsive neurosis is characterized by the persistent intrusion of unwanted thoughts, urges, or actions that the patient is unable to stop. The thoughts may consist of single words or ideas, ruminations, or trains of thoughts often perceived by the patient as nonsensical. The actions vary from simple movements to complex rituals such as repeated hand washing. Anxiety and distress are often present either if the patient either if the patient is prevented from completing his compulsive ritual or if he is concerned about being unable to control himself. (DSM-II, 40)

At first, I made the character choice of playing Nick as an obsessive compulsive, because Nick felt guilty and had hurtful feelings resulting from the loss of his wife, causing him to compensate by doing ritualistic movements in the bar. When I felt anxious I would begin to clean until I could get rid of the negative thought and emotion. It was a great way to attach Nick's emotions with his emotional life. Even though I did not in the end portray Nick as an obsessive compulsive, I did use many of the ideas and symptoms, but to a lesser extent. Making these strong psychological choices early on in the process can further develop the character and break some personal choices that are redundant.

In the field of Abnormal psychology there are unlimited amounts of resources for actors to create character choices from. In the book Maladaptive Behavior, An introduction to Abnormal Psychology, the authors discuss different forms of stress. There is acute stress that is caused by rape and other violent crimes. Chronic stress is caused by work environment, family and urban living. And the special stress of war, caused by 
seeing and being involved in violent acts, also, known as post traumatic stress disorder. There is an infinite amount of possibilities for an actor to explore in this field other than the more serious diseases like schizophrenia.

\section{Human Development}

Human Development deals with the choices we make through out are life starting from birth. Several different psychologists have created different theories about human development called ladders. The earlier the stage the lower the stage is on the ladder. When you grow up, you go through these different stages in human development. If there is a trauma during one of these stages it is possible that you will not move on to the next stage. Some of the psychologists that have created these development ladders are Erik Erickson, who created the human development ladder; Sigmund Freud, who thought up the famous Human Sexual Development; Piaget came up with the Human Cognitive Development theory and there are several other theories by prominent psychologists.

In Erickson's theory of Human Development each level of the ladder deals with the polar opposites in human development in that stage. The average person lands some where in the middle of the polar opposites.

$\begin{array}{ll}\text { Years } & \\ 65 & \text { Integrity vs. Despair } \\ 35-65 & \text { Generativity-Stagnation } \\ 23-34 & \text { Intimacy-Isolation } \\ 18-22 & \text { Individual Identity-Role Diffusion } \\ 13-17 & \text { Group identity-Alienation } \\ 7 & \text { Industry-Inferiority } \\ 5 & \text { Initiative-Guilt } \\ \text { Months } & \\ 20 & \text { Autonomy-Shame } \\ 10 & \text { Trust-Mistrust }\end{array}$

These years are a guideline and are not exact. Every person goes through these stages at there own time. Each stage is thought of by Erickson as turning points in development. And when there is great stress on a person they may regress to the previous stage or never move on to the next stage. 
Trust and Mistrust is the first problem a child must face. This stage deals with the baby being able to feel safe in the world and feel that he/she will be taken care of by his or her world. The baby's mother or surrogate mother is vital to the baby in this stage. The baby learns to trust through the mother and if the child is deprived of consistent and positive care from the mother the child will not trust the outside world. If the baby has this crisis then, as the child grows up to an adult they may never truly trust another person. You see these symptoms of mistrust often in adolescence that are in mental health programs. These children will not trust anyone, no matter what you do to break down boundaries or prove to be trustworthy. They will allow you to get so far then they will push you away, and sometimes violently. Traumas like, sexual and physical abuse causes this lack of trust. There is always a chance they will be able to have trusting relationships, but it is rare. This would be a truly deep given circumstance for an actor to explore, because the trauma is so imbedded in the character.

Autonomy Versus Shame and Doubt deals with children from age one to three years old. These children are learning to walk and talk and fend for themselves.

Autonomy concerns children's sense of mastery over themselves and over their drives and impulses. Toddlers gain a sense of their separateness from others. "I," “you," “me,” and "mine” are common words used by children during this period...Children in the second and third years of life learn to walk alone, to feed themselves, to control their anal sphincter, and to talk. (Fidler, 12)

This stage is central to the baby's confidence in himself or herself. When the parents are not too over-protective of their child it allows the baby to explore and gain some control over their lives. If the toddler is scolded for his behaviors or overprotected by the parent he/she may become ashamed and angry. "Shame implies that a child is looked down on by the outside world. It exploits children's sense of being small as they stand upright for the first time.”(Fidler, 13) This can affect children and adults later on in life. If a child doesn't pass this stage they can have low-self esteem and are unable to accomplish simple goals due to lack of confidence. They may also have shame as a result of the self perceived views of the world on him or her. These characteristics are deep within our subconscious. With enough exploration through actor games, the actor can 
find very powerful and clear character choices that become engrained in the subconscious. This takes the actor out of his head and can cause a relaxation to occur, because the actor is not thinking so hard. Having a deeper understanding of these stages and where their character fits will give the actor a better understanding of obstacles and needs caused by their given circumstances.

The use of psychology does not limit itself to just crazy characters with major psychological problems. Psychology explains how people deal with disasters, wars and growing up without a mother. It can also explain some symptoms of these problems that affect all of us. Everyone was affected by September $11^{\text {th }}$, even if we don't think about it we are changed forever. It is also possible that when these traumatic events took place that the character regressed on the Human Development ladder due to the trauma. With the combination of different psychological theories and principles it is possible to create a thorough system of character development that will be based on psychological theories. 


\section{Given Circumstances}

The play starts on Midsummer's Eve in 1996 at a sea side dacha south of Parnu, Estonia at the Rusakovs' Summer Home. My character Vassily has not visited the summer home in twenty years due to the affair between my character's father and my cousins' mother. They had a child who is my secret half sister Lenya. The affair was kept secret by our parents, but my cousin Manya and I were witness to the affair when we were teenagers. We new her mother and my father always snuck off together after lunch and we wanted to find out what they were doing. We caught them having sex in the upstairs bedroom. This was very devastating to my character. This is a major reason for my characters' lack of respect for women. There were supposedly multiple abortions by my aunt before Lenya. Lenya's mother really wanted to have the child and agreed to never see my father, Sergei, again in exchange.

My father, Sergei, was a highly decorated Coronal in the Russian Army. He was very attractive in his youth. My character Vassily had to follow in his fathers footsteps. That was very difficult for Vassily. I was also highly decorated in the Russian Army. After the split of the Soviet Union there was a conflict between many of the military leaders and the Politicians in power and the military leaders were fired. This was the same time my father and I began the family business. I decided that the two events were connected. Therefore, the military firing was the cause and our justification to begin an arms smuggling business. Our military connections with other countries put us in a position to make these deals.

My father and I were new money. Our side of the family strived after the fall of the Soviet Union while my cousins fell with Russia. Their father fell apart after the fall and never fully recovered. He stopped work and my father and I had to financially take care of them. I kept the summer dacha from returning to the original Estonian owners like all the rest of the summer houses on the beach. The beach house was awarded to my Uncle for being a military doctor. Although he was believed to be a Soviet spy and that is where he got his money and the dacha. After the fall I gave jobs to my cousins in the family business. Work for Russians became very difficult in Estonia, because the Estonians refused to speak Russian and all the Russian teachers were fired from the 
school systems. That affected my cousins Manya and Sveta. Also, Alexei, Sveta's husband, was fired from his professor job. Sveta and Alexei were givens jobs in my company after their dismissal.

One year before the beginning of the play, on Lenya’s birthday, my cousins' father died. My character was allowed to come back to the summer house, because neither of their parents were alive. There mother died many years before when Lenya was a young child. I never new about my sister until two weeks before I arrive at the house when my father told me that Lenya was my sister. I was told that I would go to the dacha to get my sister and to inform my cousins that their summer house was going to be turned into a summer retreat for our best customers.

After the summer the house was to be turned over to my girlfriend Natasha. Natasha is my girlfriend who also was very close with my father. Hayley Clark decided that Natasha was a high-priced call girl. She had me wrapped around her finger. I was very sensitive about our relationship due to the fact that I paid her to be my girlfriend, and I never new how she really felt about me, because she was paid to love me. Natasha worked both my father and me to get this house. Hayley and I decided that my father sent her along to make sure that I did not screw it up. My father could not trust me to do this job, because of my drinking problem and my temper. Also, I had many good memories of that house. Natasha was a character that was an outsider that was not close to anyone.

There was a strong clash of political and social ideas between our two families. My uncle Alexander was highly intellectual and believed in socialism. My father had strict military training that set his views. This caused many arguments at holidays when our families were together. I thought my Uncle was very pompous and that he looked down on my father and me. My feelings and ideas about my Uncle Alexander come out in the second scene when I am highly intoxicated.

You know what I find strange, listen right, what I've always wondered about for years. How come we never called your father Sacha? Never Uncle Sacha. Always Alexander. Like he was the fucking Tsar or something....I mean, how you supposed to warm to a man who’s always so bloody formal?(Kolonists, 26)

In Russia a person would have several names and you would use a different name depending on how close you were to them. It is an insult in the Russian culture, to be 
called by your formal name by your family or friends. For instance, Natasha has three names: Natasha, her personal name; Natalya, her formal name and Natashka, her pet name that only I call her. That is why my character took offence to only being able to call his uncle Alexander. 


\section{Research}

\section{Politics and the Russian Army}

The political strife between the Russian Army and its Politicians negatively affected my character Vassily, because of his military background. The break up of the Soviet Union caused there to be great dissention between the two families. Also, the break up was a direct cause of the start of the Rusakov Company. Vassily and his father took advantage of there military connections and began a smuggling business using Russian Military supplies.

In 1988 Gorbachev made some drastic cuts to the military budget. He cut 500,000 soldiers. He changed the defense industries into civilian production. In 1989, defensive procedures were cut by 30 percent. He forced the officers to organize the withdrawal and Re-basing of troops at a speed too great for the officers to handle. This caused much animosity between the military leaders and Gorbachev. These moves caused an increase in political and ethnic violence. There were no political deaths between 1968 to 1985, but between 1988 to 1991 there were 1,221 deaths due to a political or ethnic cause.

The strength of the state weakened during Gorbachev's reign. He lost the power to control private behavior. The economy broke down. The Government's power became less important, because of his lack of control; this lead to the political leaders of the fifteen republics to ignore commands from Moscow or supply resources, including men for the military. Some Republics began to form there own Armed Forces and began plans for breaking away from the Soviet Union.

The August 1991 Soviet Coup was lead by a small group of some of the top ranking Government officials in an attempt to impeach Soviet Political leader Mikhail Gorbachev. They wanted to take emergence control of the Soviet Union so they could prevent the attempts of the fifteen republics from breaking away from Russia. The strongest backer for the coupe was and military supporter was, General Valentin Valennikas, Commander of the ground forces. The coup was on the same day as the signing of the Union Treaty. The treaty was believed to lead to the break up of the Soviet Union. The coup collapsed when there was resistance formed in the armed forces. The 
military believed their major duty was external defense and disagreed with missions of internal affairs. The coupe was actually a charade against Gorbachev. After the failed coup, there was a huge dismissal of military leaders. The minister of Defense, the Chief of the generals staff and many more high ranking military leaders were fired from there jobs. The communist party backers in the Army were banned from military service. The first states to break off from the Soviet Union were Estonia, Latvia and Lithuania.

This research directly affected Vassily. Vassily's father was on the General's staff and Vassily was a high ranking officer in the army at the time of the Coup and that were thrown out of the Soviet Army due their part in the Coup. I decided that Vassily and his father were involved and backed the attempted coup against Gorbachev. I made this choice because of Vassily's dislike for the current political leaders, calling them "cowards" and preaching about a military take-over of the Soviet Union. In addition, the dismissal of military leaders gave him and his father the motivation to screw over the politicians by starting the Rusakov Company. Also, Gorbachev’s lack of control gave Vassily the means to get the materials and the support to begin an arms smuggling business.

\section{The Soviet Withdrawal from Afghanistan}

One of Vassily’s military campaigns was the Russian Afghan War. I wanted to understand what the fighting was like and how the Soviet Army was beaten by Afghanistan, because that defeat affected my character deeply. The timeline is based off of Tom Rogers book, The Soviet Withdrawal from Afghanistan.

1979 Afghanistan and Pakistan claim over 5000 guerrillas are fighting Soviet and Government forces in Afghanistan. By December, around 5000 Soviet troops were airlifted to Afghanistan. The soldiers kill the Afghanistan President and Afghan units are controlled by the soviets.

198040,000 troops sent and move to the Provincial Capitols of Afghanistan. The Soviets use poison gas on Afghan guerrillas. By April, the Soviets controlled the capitals and the guerrillas controlled the country side. The United States Boycott the Olympics that year held in Moscow and sixty other countries followed. 
1981 There have been two and a half million refugees that have left Afghanistan for Pakistan and other countries.

1982 There was a great explosion that kills one thousand people including seven hundred soviet soldiers.

1983 The resistance was stronger that anticipated by the Soviets. The fists round of withdrawals begin. A soviet deserter reported that the troop's morale was low and there was a high use of drugs by the soldiers.

1984 Soviet Forces launch massive attack on strongholds North of Kabul. They used Tanks and Armored Vehicles with 20,000 troops. The US counters by funding the Afghan Guerillas with 280 million dollars worth of aid.

1985 Seven Guerilla groups join to form an alliance to fight the Soviets. The Afghan Army looses 50,000 soldiers due to desertion, over half there man power.

1986 US Supplies Afghans with radio guided Stinger missiles. This caused major losses to Soviet Aircraft. These weapons are thought to have been the beginning of the end of the Soviet Army in Afghanistan. Moscow withdraws 8,000 men.

1987 Many Soviet soldiers have been killed while off duty on the streets of Kabul. Over 4,000 rebel forces have surrendered. Fighting continues during cease fire. Fighting is slowing down, but no-one is winning the war. The Soviet Union refuses to employ a rapid removal of troops. A month long battle in and around Kanadar left hundreds dead. Soviets are loosing steam.

Soviet Veterans of the Afghan War start a group to fight neglect by the government. Around 500, 000 soldiers served in Afghanistan and over 12,000 died. Gorbachev suggests a twelve month withdrawal of Afghanistan. Fighting continues.

1988 The Soviet Foreign Minister claims that the Soviet Union will try to withdraw its troops by the end of the year. Soviets convinced they cannot win. Gorbachev agrees to a withdrawal date of May fifteenth. In March, General Valentin Varennikov, said that the Soviet General staff was against the war, but was overruled by the civilian government. On May fifteenth the Soviet Union begins there withdrawal of one hundred and fifteen thousand troops.

1989 On Feb. 14 the Soviet Army removes its last soldier from Afghanistan. 
I found many comparisons with this war and Vietnam. Both the Soviet and American Soldiers were not used to defeat. In both instances they did not have the support from within there own countries during and after the wars. In both cases the soldier's morale was very low. The soldiers did not understand why they were fighting. There was an increase in depression and drug use by the soldiers. And when the soldiers were sent home they were not treated with respect. Even the military leaders for the Soviet Union were against the war. This caused a great split between the military and the political powers in the Soviet Union. It was also the cause of political hatred and prejudice between its people. The loss in Afghanistan was the beginning of the end for the Soviet Union.

My understanding of the specifics of the Afghan War helped my performance in many ways. It gave my character a more thorough background. It lead me to the choice that Vassily had post-traumatic stress disorder. Vassily’s alcohol addiction also began during his time in Afghanistan. Vassily was very proud of being a soldier and wanted nothing more than to follow in his father's footsteps, but everything went wrong. He did not get the praise his father received earlier in his career. These two major areas of research I focused on helped me to understand Vassily's ideas and feelings about his family and about Estonia. The research helped me see that the split between the Rusakov families represented the split of the Soviet people. 


\section{Relationships}

Manya: I think my most complicated relationship was with Manya. There were very strong feelings between both of our characters. Carrie Whitting and I talked about our relationship and came up with some interesting choices. We were good friends as children. We witnessed her mother and my father having sex; which we thought was funny at the time. Out of that family I was closest to her. Now what we added to the given circumstances was that we had sex that summer after we caught her mother and my father. We decided that after reading the play several times that there was something more there between us. Emotionally it raised the stakes for both the characters. It caused me more anxiety coming into the house to see my cousin who was also my first love. It motivated me to drink more. Also, it motivated the sexual tension that was in the script already. When I was rejected by Manya it hurt more and caused me to drink even more until I was a belligerent drunk. In an ideal world we would have come together and been lovers and been happy, at least in my ideal world. Too many bad things had happened for that to work. I had changed too much. In the third scene I call her pompous, because she thinks she’s smarter than Natasha. "No your right Manya. Why bother telling Natasha here. Bound to be way out of her league. Is not it?”(Kolonists, 54) Vassily felt that they were elitists that looked down on his family.

At the dinner table, Manya makes several remarks about me being a crook. This definitely built the tension between us. I then force Manya to tell the family about our secret. The scene escalates to its climax when she tells me what she thinks of me.

You're a coward, Vassya. Afraid of your father and the competition. Scared of flying and all those lonely hotel rooms. Worried about your weight, your hairline, your bad breath. And, of course, terrified the woman you have to drown in cash won't stay the night. (Kolonists, 85)

Those statements are devastating, they are also true. They are all my fears and the things I hate about myself. But I can see right through her as well. I call her out on her father and how he allowed her fiancé to get his fucking head blown off. That line was the finisher. One line later shows how I truly have the upper hand. "My House.” (Kolonists, 
85) No matter what she said about me I was in control. From the beginning I was in control. Manya was the last for me to destroy in this play. My main reason was because I cared about her the most. I couldn’t do it first, because it was painful. The other reason was, because she was the family member that was the least in denial. She new what I was doing so I had to wait to find a way to get to her.

When I walked into that house I did not want things to go the way they did. I wanted to drink and have a good time. I wanted to see Manya and talk about the past. Talk about what happened between my father and her mother. I was hoping we could tell them about the affair together and that Lenya would be allowed to go to Moscow to meet our father. I was also thinking that we could let the family in on the idea about the conversion on the house and they would understand. I made those choices because I needed to have positive objectives to play. My rejection by Manya and the others were the cause of my actions.

Natasha: Natasha is my love interest. She is the one I have true feeling for in this play. I think she’s spoiled. I call her a slut. I call her my “traveling companion” not my girlfriend to Manya. She is the one character though that can make me vulnerable. Natasha knows all my traits. She knows when to step away from me when I get violent. She knows how to calm me down. After I leave in the second scene to take a piss, Natasha talks about my personality to Manya. She says,

Vassily, he has this problem relaxing. He’s edgy, see, can not keep still. Strange places affect him. I don't know why. He traveled all over the place in the army. To hear him talk there's nowhere he hasn't been posted....You don't know him very well, do you, Manya? The man's never happy. His throat's dry, his feet are cramping up, there's pains in his chest, the plane is gonna crash! I got these pills I give him on nights like these. Two or three of 'em usually shut him up. (Kolonists, 30)

He also gets very jealous of Natasha. He does not trust her. He sees how his cousin Andrei is with Natasha and it really irritates him. Even though he has strong feelings for Natasha, when he is drunk, he does not treat her with respect. "Natasha! Get your ass in gear! You hear me? Natasha! You-you-you want to come up there!”(Kolonists, 27) 
Two minutes later I am begging her to never leave me. “...don’t ever leave me Tashka, so beautiful in your boots. Sexy boooooh-tsa! My Natasha.”(Kolonists, 27) Vassily sees women as a possession. And Natasha is his possession in a way, because he bought her. Unfortunately for Vassily he can not buy her love.

Another complication in their relationship is Natasha's relationship with Vassily’s father. I had a line at the end of the play when Natasha reveals the information about Lenya being my sister. I say, “Natasha and My father are very close.”(Kolonists, 79) That line could mean several things, but due to my insecurity in our relationship we decided that they had sex. And after they had sex my father told Natasha about Lenya.

I learned a lot about Vassily from what Natasha tells the other characters in the play. Also, there is a lot of information about our relationship and how I treated women by what I said to Natasha and what I said about her. Natasha knows Vassily better than anyone and uses it to get what she wants. She knows how to get him jealous and she knows how to calm him down.

Andrei: Andre is my cousin. My father also hired him to be my lackey. He does what ever I tell him to do. I do not respect Andrei. I think he is a coward and a weakling and he won't stand up for what he believes. Andrei also dodged going into the military by getting a note from his father saying he was sick. A choice that Max made was that he was depressed and was unable to go to war. But I did not know that and still would not have considered depression a disease. I would see it as a weakness.

Andrei flirts with Natasha all the time as well and that irritates me. In the second scene when Vassily is drunk he calls Andrei on the fact that he knows that Andrei is hitting on his girlfriend.

Don't play the innocent. I've seen you horney little creep. D'you think Natasha'd look twice at a gutless prick like you? A girl like her? Not in your wildest wettest dreams, you hopeless little wanker.(Konlonists, 26)

I put Andrei down because he is a threat to me and I want to keep him down. I do not trust him. And at the end of the play I destroy him like the others by telling him he's a coward and blamed Manya’s fiancé's death on people like him. 
Alexei: I don't meet Alexei until the third scene of the play. But I have heard a lot about him. Alexei looks up to Vassily and is very nervous about meeting him. He doesn't know what he will be like. He is initially intimidated because he is an intellectual in a businessman's world. He reminds Vassily of his Uncle Alexander. Vassily has something to prove to him. The debate they have in the third act was the same as the arguments Vassily talks about with his father and his uncle. Alexei's intellectual views of the situation with Estonia are the exact opposite of Vassily’s. Vassily has a military point of view; experiencing the world by living in it. Alexei gets his views from books. That is why Vassily feels Alexei’s ideas lack validity. For instance, when Alexei is preaching to Lenya about the need to learn Estonian, Vassily attacks Alexei’s views.

Professor, you're talking out your ass. This endless discussion, hethe-the search for some kind of convergence, some sort of mutually beneficial exchange of philosophical...crap. It stinks. A man should learn a language different from his own only when he finds it expedient to do so. In order to infiltrate, to subvert, to dominate his enemy. (Kolonists,73)

Vassily attacks his views and justifies his ideas with a solid example of why he learned the multiple languages. Alexei also is a supporter of the Estonians which Vassily is against. Vassily believes the Estonians were traitors for leaving the Soviet Union. He actually claimed that they were Nazis and Nazi sympathizers.

Sveta: Sveta was in denial. That was the problem Vassily had with her. He doesn't talk about spending a lot of time with her when they were kids. But her denial about the affair really irritated Vassily. Sveta is the same age as Vassily and she must have had a strong feeling about their affair. Sveta is a lot like the mother of Lenya. Lenya's mother died at an early age and Sveta had taken care of the motherly duties of the family. Vassily has to be brutally honest about the affair, because Sveta was in deep denial about the affair and the possibility that Lenya was my sister. She then tells him to respect her father in his house. Vassily then snaps.

My house, Sveta! This is my house! Do you understand that?...You're lucky I don't throw you all into the street. The way 
you look at me, the way you-piece of shit that I am. Fuck you!!! (Kolonists, 81)

Sveta makes a strong attempt to stop Lenya from going to Moscow. This is Vassily's major problem with her. He must destroy her to ensure Lenya has no reason to stay. Also, by showing Sveta's faults he gets closer with Lenya, because of their rocky relationship.

Lenya: Lenya is Vassily's long lost sister. Vassily goes to Estonia to bring his sister home to meet their father. He has very positive feelings for her. A lot of Vassily's negative acts are for her. In Vassily's mind he is doing the right thing. He is saving his sister from a family based on lies and illusions. Vassily reveals their illusions in front of Lenya to bring them closer together. He also hopes to break her ties to home so she will leave with him. Lenya has a lot of Vassily's father in her. She comments at the end of the act that the family is living a lie. Lenya also is not the intellectual that her sisters are.

Vassily is thirty eight years old and is not married and probably never will be. Lenya gives him an opportunity to take care of someone. Lenya is someone who could love him unconditionally. Due to Vassily's flaws and mistakes he will not get that from another woman. Vassily lacks love and affection. And he takes many strives to get that somehow. Vassily sees Lenya as a chance at redemption. His mother is only mentioned once in the play and seems to be a non-factor is his raising. His love for Natasha has been corrupted, because he pays her. Therefore, he must seek it somewhere else. Also, Natasha will be leaving Moscow to run the business at the house. Lenya could be a replacement. When Vassily meets Lenya, he slowly kisses her mouth. This need of affection drives Vassily to defend Lenya and to split her up with her fiancé Kolya. Lenya needs Vassily as well. She is tired of her family and their lies. She wants to escape and explore the world.

Without Vassya what would I be now? Still a cleaner. Scrubbing police cells. God knows what else... But thanks to Vassya, I don't need to rely on you, Kolya. Thank you very much. I can have something different. Who knows, this way I might even get to leave home before I'm carried out in a box. (Kolonists, 78) 
Kolya: Kolya is in an unfortunate position of being the fiancé of Lenya. Before I arrived I knew I would have to get rid of Kolya first, before I could have Lenya. Kolya is a poor cop that doesn't deserve my sister. He is week and doesn't have the drive to make anything for himself. He dresses poorly and looks like a fool. He is still stuck in the old world of Communism. He did serve in the army, which I respect. He also thinks like I do in some areas politically. But in the end he will never become anything. Lenya doesn't love him and he has nothing to give her. But Lenya did love him and she is still with him so something had to be done.

Natasha and Vassily set up Kolya by catching him staring at Natasha's breasts. Then they threaten him by implying that they would tell everyone that he was sleeping with hookers and stealing money from the job. Vassily barely had to do anything, because he was on the way out anyway. Yakov: Yakov was the physical threat to Vassily. He attacks Vassily while he is drunk and having sex with Natasha. Vassily threatens his life after he had been knocked out and dragged onto the stage. After he is passed out again Natasha threatens Yakov, saying that I would cut of his penis and that if we were in Moscow there would be problems. "If this happened at home, it'd be all over town by now...All hell'd be let loose. You know what I mean? Reprisals.” (Kolonists, 47,48)

If Yakov were in Moscow and did not know Vassily's family he would have been shot. Vassily is embarrassed the next day that he was beaten up by the help. Even after Yakov apologizes, Vassily takes a shot at his last name calling him Jewish. Vassily wanted to show he was not afraid of him. He needed to regain the power in their relationship. When Yakov hit him, he made Vassily look like a fool and that comment helped him regain some of his status. Although in the end he was still intimidated by Yakov, because of the shot he took the night before. Yakov ends up being the only successful person to stand up to Vassily. 


\section{Rehearsals and Performances}

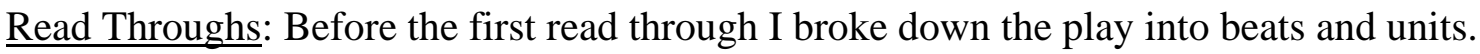
That work helped me have a clear understanding of the through line of the play and my character. I also had my research completed and ready to present. I learned a lot of information about the play and my character at the reading.

I learned about Estonia on Midsummer's Eve. How it's a strange holiday. It's a very pagan holiday with sex and drugs. It is a day that anything can happen. Also, during June it never gets totally dark. It's the light season. This can cause people to be anxious and make people drink and fight more.

We also talked about the idea that Vassily and Natasha are characters from Harold Pinter's The Homecoming and my cousin's family is from Chekhov's Three Sisters. I like that comparison because I know both those playwrights' styles from previous work. Vassily and Natasha are all about business and power. Vassily lacks a mother figure, like Lenny and his brothers in The Homecoming. He disrespects women and uses his physical presence as a weapon to gain status over women. Yet he is controlled by a woman, Natasha. He seeks her affection, though he does not respect her as his equal. Natasha uses her sexual powers to gain status from Vassily and the other men in the play.

Phil Beck the director helped me to realize that coming to this house had to be difficult for Vassily. At the beginning of the play I had to remember having fun with my cousins, and playing on the beach. There needs to be some shame for the man I became. I am now going to my family’s summer dacha and turning it into a Brothel. My justification is that I've been carrying these people for years and paying their bills. I can do whatever I want with that house.

Clothes make the man. It shows how powerful I have become since the fall of Russia. People will respect me. Clothes are a new symbol of power to the Russians. During Communism you weren't supposed to wear clothes that made you look more important that other people. Vassily’s clothes are a symbol of new money in Moscow.

On September twenty ninth I worked on relationships. I need to fool around more with Manya. We were close friends when we were kids. We had a very weird relationship that I need to explore further. 
I am vicious with Andrei and very short with him. Max Arnaud and I came up with the fact that I am jealous of his relationship with Manya and Natasha. When I'm alone with Manya, I'm much nicer, but once Andrei walks in the room I become nasty. I want him out of the room so I can be with Manya alone. When Natasha flirts with Andrei it embarrasses me. So I degrade him afterward to get back at him.

I also explored the idea that I have betrayed my country selling arms to Libya, Iran and North Korea. Those are my clients.

On October fifth, I was working on having more levels in my character. Vassily was one level. He was too much of an asshole at the beginning. He needs to be funnier, childish a whiner. Also, Phil told me to take my time and not rush the scene. The character seems false to me right now. I need to explore what memories are good and what memories are bad. Furthermore, why have I truly come to this house?

Phil agreed with me that Vassily is an alcoholic. But he added that today is even worse, because of the circumstances. I fully agree with that idea. That makes that day more important than the others.

Second week of rehearsals: I need to play the opposite more often. I don't need to play powerful, because I already have power. I still need to find levels and playing the opposite will help.

I received the note that I need to go back to the script and see what my operative words were and what lines I can throw away. In Act III I need to tell the story more clearly. I need to figure out what Alexei says is important to further my points. I really need to ask the questions during the whole play. I am not looking for an answer. I need to find the seven year old child during the drunken scene. "Someone stole my fucking shoes.” (Kolonists, 28)

Again, asking questions are still a problem in my performance. I need to look for the answer. Ellipses are not pauses. In act III I need to keep the pressure on the other actors. I need to be on top my cues. Need to find Objectives.

Third week: Act II. I have to want to party. It's a positive objective. This act is getting better. I am working on the rhythm of the act, especially with the dry heaving and drunken section of the act. 
I have been using my psychology research to create levels and make some choices. I've been looking at how drunks have emotion swings from positive to negative. I also can be colder when I am drunk. Understanding the mood swings of a drunk really helps me transition smoothly from rage then immediately to the joy. When intoxicated I have no control of my emotions or my thoughts.

I have also been trying to envision my flashback during the Kolya scene in act III. The flashback is of a battle where my friend was shot in the head. His face is gone. I don't know where the sniper is hiding. There was an ambush and people are being shot everywhere. I'm responsible. I'm scared. I'm in Afghanistan. It's very rocky and all I can do is hide behind a rock and look at my dead friend and listen to men screaming. I am numb. At this point I break out of the flash back and have a drink.

I am also playing with envisioning my father having sex with my Aunt when the secret is revealed in the third act. Do not know what I'm seeing at first. Then I realize. I have flashes of different moments, positions. My aunt is on top of my father she is very attractive. I blame her. It's her fault my father cheated on my mother. Afterwards we go in Manya's room and have sex. I want to try it on Manya. That was my loss of innocence. I did not treat women with respect after that day. November $2^{\text {nd }}$, Full Run: My energy and volume is dropping at the end of my lines. I need to drive to the end of the line. I need better vocal stamina for Act III. When I ask questions I am dropping energy. This is a major problem for me. I need to be clearer with my intention to the end of the thought. I have to find all the levels in the story in the second act so my points are clearer.

November $3^{\text {rd }}$, Full Run: Act II I found a lot of energy by really wanting to party. I have been having a problem with my Natasha Slut monologue. Phil suggested that I say it directly to Manya to see her reaction. Play it more as a joke.

Dress Rehearsal 1: Tonight I slipped into old habits. I did not drive to the end of lines. My feet did seem like they really hurt. When I was drunk it did not seem like the world was spinning. I need to play with Jerry’s exercise to get me where I need to be for that scene. I will do some sense memory drunk work and come back tomorrow stronger. My acting is too cautious. I need to relax and take some chances. Listen and react to what my other actors are giving me on stage. 
At the end of the play, my line: "You pathetic cunt.” That line doesn’t need to attack vocally. The words themselves do that. All I need to do is say the words and mean them.

Final Dress: The rehearsal was pretty crappy. I need to stop force acting. I need to relax and react. I am not in the moment. I am trying to force the performance. I did have some nice moments. But I did stop asking questions again. I need to take more time in the second act. Phil told us to "Riff off each other." That will be my goal for our first preview.

Preview: I was definitely more relaxed tonight. I was talking more with the other person. I made some major strides. My story telling in Act III was good. And the audience was able to get the nuances of the play. There was a small audience, but they were nice and were able to follow the action of the play.

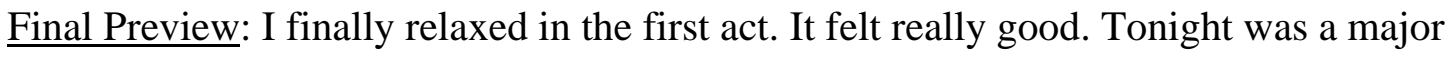
breakthrough in my acting. I really connected with Manya. Carrie Whitting (Manya) thought that I was much scarier this time, because I was so relaxed saying these awful things. The dinner scene also was great.

Unfortunately the audience was very disrespectful. Students were talking on the phone, laughing and dropping things in the aisles. It was very difficult to focus on my work. I was very close to standing up and telling them to shut up.

Opening: Audience was very supportive. But the laughing was too much. It distracted from the show. I felt I had a good show, but because I was nervous I was not as relaxed on stage at first. But after I found that relaxation the night before, I was able to relax as the play went along.

Saturday Performance: I was low energy but I was very relaxed. I keep forcing the first scene and I know I do not need to, because I have found this character. It's been great working with Max and Carrie in this play. I have learned a lot from them.

Two for Tuesday's: The audience was wild today and I really fed off them. I got the audience on my side. The audiences' reaction to some of my lines really charged Vassily's attitude. After talking to the playwright I noticed I was playing him too nice in the first act. I made some adjustments and I liked it. I felt more like a powerful businessman in the scene. Also, I realized that Vassily comes in with all the cards in his 
hand. I think I have found a balance of him wanting to party and wanting the day to go smoothly and wanting to put them in their place.

Wednesday Performance: I am finding the character even more. It was a good performance. The audience was weird, but they loved my character.

Thursday Performance: Talked with Seteney Yener and Magalie Naas today about the stage fight in the third act. I really could not believe it. So I gave them a suggestion and they tried it and it worked. It really helped me tonight believe the slap. My blocking is to jump up after the slap and I really could not react naturally to it before. I felt stupid, because the slap was too slow and they were both tentative. This time it looked awesome. I feel that stage violence needs to shoot the action of the play to another level; if it does not do that then it causes a major brake in the action of the play. These acts of violence cause a natural psychological reaction from the actors if it is believed. For example, in Constantine Stanislavski's book The Actor Prepares, he talks about an actor picking up a gun and putting it to his head. That physical action of picking up a gun and putting it to your head should cause a natural psychological reaction.

Friday Performance: I had my best first act tonight. I was focused and listening. Every line was specific. I was playing my objectives. My breathing was even on. I really meant what I was saying on stage. But after intermission I began thinking how great it was going and no longer was in the moment. I started fumbling lines and lost the through line of the argument and had to improv my way out of it. I just couldn't get out of the funk. Last Performance: My performance was consistent all the way through. The slap was great and I trusted it would be there tonight. That was the first time the end was there for me. I really hammered the dinner scene I found the argument and was able to bring the audience along with me. Vocally I found the levels needed to keep it interesting. I wish we had another two weeks to perform. I feel it all came together today. Performance Review: I found Vassily's point of view with a lot of help from Phil Beck the director. I was able to contrast his political views with his family relationships and the result was an interesting believable character with many levels. The cast was successful at telling the story clearly. That was very difficult I found because the dinner scene required such focus from the actors and audience. I wish I was off book earlier so I could have explored more of my characters beliefs in rehearsal. But by the end of the run, I 
think this was my most in depth character I have ever performed. The psychology helped me fill in gaps in my character and added emotional depth to Vassily. I wanted it to assist me in creating character and then I could forget it. I feel it worked. I was able to create some very specific moments on stage. I would have liked to have worked one on one with Don Fidler on this project more, but there just was not enough time. 


\section{Closing}

At the beginning of this thesis I posed a question, does the study of Psychology benefit the actor in creating a character. I found during the acting process of Kolonists, and while writing this thesis, the answer is, yes. Psychology assists the actor to figure out the character's given circumstances. While working on this thesis I realized why and how Vassily was so sick in the head. When doing my research on the Afghanistan War and the fall of the Soviet Union I found where Vassily began to drink and where he began having horrible dreams about fighting. No characters want to be the bad guy. Something needs to go wrong in there life to cause them to act out. For Vassily, he wanted to be the romantic hero, like his father, but after the war it could not be the case. In response to loosing his dream, he became bitter and began drinking. The more he drank the worse he became around other people. He treats women like objects, because he was witness to his father having sex with his aunt. His anger towards his aunt at that early age destroyed his chances of having a normal relationship based on trust. When Vassily enters the play he is thirty eight years old. He comes there to find his younger sister and bring her back to his father. Vassily is at the stage of, Generativity vs. Stagnation in Erickson's Ladder of human development. A person at this stage wants to do things for the next generation, have children, think of the future and give away money. But if there are problems in their development the person accomplishes nothing, they fight, drink and have drug addictions, caused by traumas earlier in their development. They want to put there name on everything and want to be remembered. Vassily falls into this stage clearly, he had traumas at an early age and has PTSD from the war and he is a violent drunk. Understanding this helped me find a great objective for Vassily. Vassily needed to break his pattern. He needed to help Lenya so he could save himself, but unfortunately he could not do it. Psychology helps the actor link the past to the present giving the actor stronger needs and objectives.

One note that really stuck out I received, from Phil Beck, during rehearsals that I understand now is that all characters have a positive objective. Vassily's super objective was to be the hero like his father. That dream was altered by traumas and by the world's 
view of him. Vassily could never reach that goal, but he never stopped trying to be the hero.

I thought my process in the play, Kolonists was a success. I think I could have done more research at the beginning of my process. I now know at the end of my process what I needed to do at the beginning of my actor process. With the help of my director, Phil Beck and with the aid of Don Fidler, I have found for myself a system for acting that helps me create a believable character based on, given circumstances, research and psychology. 


\section{Work Cited}

Ciminero, Anthony and Benjamin B. Lahey. Maladaptive Behavior, An Introduction to Abnormal Psychology. United States of America: Scott, Foresman and Company, 1980.

Diagnostic and Statistical Manual of Mental Disorders, Fourth Edition. Washington DC: American Psychiatric Association, 1994

Dykes, Steven. Kolonists. Beck ts. West Virginia University, Morgantown.

Fidler, Donald, comp. Developmental Outlines. West Virginia: West Virginia University, 1999.

Fidler, Donald. Human Development. West Virginia University workshop, West Virginia, May, 2003.

Galeotti, Mark. Afghanistan, The Soviet Union's Last War. Oregon: FRANK CASS c/o ISBS, 1995.

Krasner, Leonard and Leanard Ullmann. A Psychological Approach to Abnormal

Behavior. New Jersey: Prentice Hall, 1975.

McGonigle, Jerry. Sense Memory. West Virginia University graduate acting class, West Virginia. 2003.

Rogers, Tom. The Soviet Withdrawal from Afghanistan. Connecticut: Greenwood Publishing Group Inc., 1992.

Saroyan, William. The Time of Your Life. New York, 1939. 
Shakespeare, William. The Riverside Shakespeare. New York, Hughton Mifflin Company, 1974.

Stanislavski, Constantine. An Actor Prepares. New York: Theatre Arts, Inc., 1964.

Taylor, Brian D. Politics and the Russian Army. New York: Cambridge University Press, 2003.

The Committee on Nomenclature and Statistics of the American Psychiatric Association.

Diagnostic and Statistical Manual of Mental disorders, $2^{\text {nd }}$ ed. Washington DC: American Psychiatric Association, 1974.

Weaver, John. Disasters: Mental Health Interventions. Florida: Professional Resource Exchange Inc., 1995. 


\section{Résumé}

Height: 6'3"

Weight: 220
Hair: Brown

Eyes: Hazel

Email:neilaustin01@yaoo.com

\section{$\underline{\text { Selected Roles }}$}

\section{West Virginia University}

The Winters Tale

Kolonists

King Lear

The Time of Your Life

Boy Gets Girl

Three Sister

Getting Married

Canterbury Tales

Picasso at the Lapin Agile

Ghost Sonata

The Laramie Project

Salem State College

Cloud Nine

Much Ado About Nothing

Guys and Dolls

La Bete

Sandwich Makers...

Phaedra

\section{Dean College}

The Country Wife

\section{Film}

Shadow Glories

The Man Who...

The Perfect Storm

The Rants

The Road Show

Role
Camillo
Vassily
Gloucester/ Albany
Nick
Howard
Kulygin
Boxer
Knight
Freddy
Benngston
John

Edward,J oshua

Claudio

Brannigan

De-Brie

Bob the Night

Theramines

Harry Horner

\section{Director}

J erry McGonigle

Phillip Beck

Lou Rackoff

J erry McGonigle

Phillip Beck

J erry McGonigle

Bob Leigh

Theresa Davis

Dr. J ay Melarcher

J erry McGonigle

Phillip Beck

David George

Michelle Nichols

David George

Celina April Sky

Dan Dipitro

Brian Twomey

J im Boregard

\section{Training}

Voice training: $\quad$ Kate Udall, Emelda Villalon and Wendy Hagenow.

Movement training: J essica Morgan and Tom O' Conner

Text Analysis: $\quad$ Frank Gagliano, and Bob Leigh.

Actor Training: $\quad$ J erry McGonigle, Phillip Beck, Theresa Davis, David Allen George and Celina April Sky

Film acting: $\quad$ Ziad Hemzeh, Phillip Beck

\section{Special Skills}

IP training with Kate Udall, Fight Captain, Fencing, Arnis(Martial Arts), Professional Video and Digital Camera Man, J uggling, Athletics, Ghost Hunting.

\section{Education}

BA in Acting with a minor in Psychology, Salem State College, 2000. 
MFA in Acting, West Virginia University, 2005. 